\title{
Challenges to Primary School Teachers in Multigrade Schools and Their Possible Solutions
}

\author{
Gulzar Ali kaka* Mehboob Ali Dehraj Anila Hanif Rao Muneer Nazeer memon \\ Faculty of Education Shaheed Benazir Bhutto University Shaheed Benazirabad
}

\begin{abstract}
Teacher has a central position in school and whole academic process. If the teachers have challenges in the classrooms; the child's education would severely be disturbed. There is a dire need to explore those challenges in order to improve the primary education. The purpose of this study is to investigate the challenges to primary school teachers in multigrade classes and seeks their possible solutions through available literature and discussion. Qualitative research using focus group discussion method was applied. Data was collected from those primary teachers who teach in multigrade schools. A sample of 30 participants including 6 head teachers and 24 assistant teachers was selected through purposive sampling method. Findings of study explored the major challenges to primary teachers in multigrade classrooms include curriculum design which is prepared for mono grade classes, class room management in multigrade classrooms, lack of trainings for multigrade classrooms, course completion problem, lesson planning, lack of skills, no any extra incentive for multigrade teachers, scarcity of teaching materials. Available literature and discussion have suggested possible solutions include willing teachers might be sent to multigrade schools, appropriate peer groupings like ability group, mix age group, mix ability group, playing group may be made, activity based learning would be more fruitful, lessons may be planned in such a way that similar topics merge in one topic, use of different type of flash cards and class rooms may be managed in such a way that it would be friendly for a child. Study is important because it provides a road map for teachers and policy makers to enhance quality of primary education. Research has also recommended that multigrade class pedagogy as an instructional technique may be included in trainings' manual, teachers' appointment for multigrade schools may be made separately or willing teachers would be selected for trainings and posted them in multigrade schools. Keywords: Challenges, Primary Teachers, Multigrade Schools, Multigrade Teaching

DOI: $10.7176 / \mathrm{JEP} / 10-28-08$
\end{abstract}

Publication date:October $31^{\text {st }} 2019$

\section{INTRODUCTION}

Multigrade teaching is not a new subject in formal education setting. Taole, M.J. (2017) identified that the practice of multigrade teaching is experienced in developed as well as developing countries throughout the world. Multigrade school are not only limited for class one to five but continues upto class ten; however the secondary and higher schools are limited and the teachers are almost sufficient in those schools so less need of multigrade classes is felt in those schools (Moeini, S., Moradian, N., Khoroshi, P.2016). Furthermore the primary schools in rural areas are managed in one or two rooms having almost one or two teachers who are managing almost five classes. In these schools the difficult situation is that teachers are managing multigrade classes and multi subjects in one or two rooms. This needs techniques and strategies to manage these classes as Mulaudzi, M. S. (2016) pined that multigrade classes are not same as monograde classes so the different skills and techniques are needed to teach in those schools. It is difficult for one or two teachers to manage multigrade classes. Beithammer, E., et.al (2016) noted that almost 250 million children are studying in multigrade schools and this ratio will increase upto 300 to 350 million in coming two to three years. Population of Pakistan is divided in rural and urban and $60 \%$ population lives in rural areas and $80 \%$ children from rural areas , 60\% children from urban areas are getting education in multigrade schools( Qureshi, A.J., Bhutto, A., Mahar, P. R.2019) Furthermore the major concern is not giving to multigrade pedagogical techniques. This decreases the quality of education, increases drop out ratio, child retention in schools and poor performance of the students and low attendance of students. More attention is needed to multigrade teaching because of one or two teachers teach more than one class collectively. These schools are usually located in rural areas where the transport is not possible and they need a quality education within their premises. Such system of teaching requires creative pedagogical teachings for multigrade classes. Despite their acknowledgement at world level; the Government of Pakistan has not taken a committed issue on priority level. Education department either country level or province level are striving for capacity building of teachers without acknowledging the real fact. Such trainings are useless for the teachers where they are sent to multigrade schools. No doubt that financial crisis of the province donot permit the government to establish new infrastructure and appointments but within old infrastructure and limited resources we can achieve the best results. Dr Muhammad Memon rightly said in his article published in dawn 2012 that education department should need to focus multigrade teaching as instructional strategy. Teachers are facing lot of challenges in multigrade schools. This research intends to explore current challenges to primary school teachers in multigrade schools and seeks to explore the possible solutions through available literature. 


\section{OBJECTIVES OF THE STUDY}

$>$ To explain the concept of multigrade teaching in multigrade schools.

$>$ To study the current challenges to primary teachers at multigrade schools.

$>$ To find out possible solutions of challenges through FGD and available literature.

\section{RESEARCH QUESTIONS}

- What is multigrade teaching and multigrade schools?

- What are the current challenges to primary school teacher in multigrade schools?

- What are the possible solutions of challenges faced by the teachers in multigrade classes?

\section{RELATED LITERATURE}

"Multigrade" is not a new concept for the educationists of the world but it is known with different names like non graded, multilevel, composite classes or multiage classes (Soofi, Z., Akhtar, et.al.2015, Khan, et.al. 2017). Multigrade teaching is defined in different ways but the context is same for all. Berry, (2010), Cornish, (2010) as cited in Taole, M.J. (2017) defined it as the class room in which a teacher has to teach the students of different grades. Barbetta, G. P., Sorrenti, G., Turati, G.(2018) identified that multigrade teaching is not only practised in developing countries but also experienced in developed countries like 28\% schools in United States, France 37\%, Finland $70 \%$, Netherland $53 \%$, Italy $20 \%$. This is another discussion either the multigrade classes are by choice or by need. UNDP started Millennium Development Goals (MDG) which focused on the universal primary education upto 2015 and different countries tried to achieve the target of MDG by setting multigrade schools in rural areas where one teacher was appointed to teach multigraded students in one class room. According to MDG task force monitoring report (2015) the major gaps were found regarding enrolment of the students. Now the sustainable Development Goals (SDG) by UN in which quality of education is focused. UNESCO (2015) suggested multigrade as an important tool to assist the developing countries in order to fulfill the mandate of EFA parameters. However a teacher in multigrade school has a sole responsibility as teaching role and principal role; so he felt lot of challenges in those schools. According to Khan, S., Farooq, R. A., Irshadullah, H. M. (2017) the teachers are not willing to go in multigrade schools due to burden of all classes and subjects. Pakistan is facing lot of financial crisis so the then government formulated an education policy in which private persons were allowed to open private school and these schools were almost opened in urban areas (Dayan, U., Perveen, S., Khan, M. I. 2018). Rural areas were pushed back in the field of education. One or two teachers in those remote areas were sent to teach three to five classes and the teachers are facing lot of challenges in those multigrade schools (Moeini, S., Moradian, N., Khoroshi, P. 2016). Tiernan, B., Casserly, A. M., Maguire, G. (2018) said that teachers are sent to multigrade schools who have no any experience of teaching in multigrade schools and they face lot of challenges resulting the education of rural areas is severely disturbed.

\section{RESEARCH METHODOLOGY}

Qualitative research using focus group discussion was selected for data collection. FCD is the best technique for deep understanding of the problem(Cohen,et.al,2007) Respondents for the research were selected through purposive sampling. It is the type of non probability sampling. Participants were selected on the basis of their experience, performance and interest. The group members were free to view on every dimension of the topic. Three focus group discussions were arranged for the research. Average timing of discussion was one hour. Researcher arranged three focus group discussions in order to avoid any biasness.

\section{POPULATION}

District Matiari was selected as population of the research. From the information obtained through the district government of Matiari there are 980 primary, secondary and higher secondary schools working in which 880 are primary schools. These 880 schools include almost 550 schools in which one or two teachers are working.

\section{SAMPLING}

Purposive sampling method was used for data collection. District Matiari consists of three Talukas includes Matiari, Hala and Saeedabad. A sample of 30 participants from Taluka Saeedabad was selected. 10 participants were selected for one focus group discussion. The detail is given below: 


\begin{tabular}{|c|c|c|c|c|}
\hline Total Participants & Focus Group: 1 & Focus Group: 2 & Focus Group: 3 & Data Required \\
\hline 30 & $\begin{array}{l}\text { Head Teachers: } 2 \\
\text { Assistant } \\
\text { Teachers: } 8\end{array}$ & $\begin{array}{l}\text { Head Teachers: } 2 \\
\text { Assistant } \\
\text { Teachers: } 8\end{array}$ & $\begin{array}{l}\text { Head Teachers: } 2 \\
\text { Assistant } \\
\text { Teachers: } 8\end{array}$ & $\begin{array}{l}\text { 1. Challenges to } \\
\text { Primary teachers } \\
\text { in multigrade } \\
\text { Schools. } \\
2 . \\
\text { solutions Possible } \\
\text { challenges. of }\end{array}$ \\
\hline
\end{tabular}

\section{DATA ANALYSIS}

Collected data was analyzed into themes. Thematic analysis is the best qualitative research method to analyze the rich data. Qualitative data is descriptive and detailed in nature so thematic analysis narrows down the rich data in a summarized way.

\section{RESULTS AND FINDINGS}

In this paper, the researchers report the perspectives of teachers and head teachers related to the multigrade classrooms and the challenges faced by them. The experienced participants were selected who worked in multigrade school since more than decade. Findings are categorized into following themes.

\section{Theme 1: Class Room Management}

Class room is like the laboratory of the school where all the activities are performed by the students and judged by the teachers. Almost all the participants asserted on the class room management as a big challenge because the monograde setting of classroom contain only one grade but multigrade classroom setting is different one and needs a disciplined strategy to manage. Most participants shared their experiences "we manage the classes into three sections like class ECE and one into one section, class two and three in section into two section and class three and four in third section". Enayati, T.,Zameni, F.,Movahedian, M. (2016) suggested that groups of the students must be assigned the task and role of teacher would be the monitoring and teachers must think another task before completing the given task because in this way class room management would not be disturbed. Hyry-Beihammer, E. K., Hascher, T. (2015) advised a strategy named "Peel off" in which the teacher gives separate time to prepare for a planned task, when the students get prepared for that task they come on their desks and perform the task. Muthambi, S. K. (2016) proposed a peer tutoring strategy to manage multigrade classrooms and increase performance of the students in those classes. Furthermore he shared the finding his study in which he made two groups; one experimental group and other control group, he found that peer tutoring strategy group showed more results than control group. He recommended peer tutoring as a best strategy in multigrade classes.

\section{Theme 2: Curriculum Structure}

Curriculum is the road map for school and teachers. A teacher is the implementer of curriculum in the class. As the multigrade setting of the class is totally different from the monograde so it needs a different road map. Current curriculum addresses only monograde classes. The topics have little alignment create major hindrances for teachers to manage multi classes within limited time. Taole, M. J. (2017) proposed that curriculum of multigrade classes need to include such topics which are integrated and easy to select a common topic for multigrade class.

\section{Theme 3: Lack of Skills in Multigrade Multigrade Teaching (MGT)}

Brown (2008) as cited in Taole, M. J. (2017) identified that multigrade teachers are different from others and they need not only deep understanding of the subjects but also need strategies and skills to deliver the ideas which can be more accessible to the learners. Majority of the participants acknowledged that teachers almost take trainings of monograde classes, so they lack skills of multigrade classes. Majority of the participants denied to participate in any training conducted by the Education department. They all asserted that no any training pertaining to MGT has been organized by the education department however one of the participant affirmed to participate in a training organized by Agha Khan University on the multigrade teaching. Nawab, A.,(2011) as cited in Khan, S., Farooq, R. A., Irshadullah, H. M.(2017) conducted an action research study on strategies of MGT with the name School Improvement in Multigrade Situation (SIMS) in four Project schools of Karachi, said that the course enhanced the pedagogical skills of teachers and learners' performance.

Theme 4: Equal Incentives for Monograde and Multigrade Teachers

Participants argued that the multigrade teachers work load is more than that of monograde but the government incentives are equal for both classes. Participants further said that a teacher in multigrade is bound to remain in the class because his one casual leave affect the whole school, so a teacher usually doesn't avail the leaves but there is equal incentive for both type of teachers. Mulaudzi,M.S. (2016) in his research acknowledged that the teacher in monograde school avail more leaves than that of multigrade school. After such acknowledgment, the multigrade teachers deserve more incentive than monograde teachers. One of the participant argued that as the 
different teaching staff posts are advertised by the Education department like PST, JEST, EST, SEST, ECT, the multigrade posts may be advertised separately as MST (Multigrade School Teacher) BPS-12 or 15. Another participant suggested that Education department might select the willing teachers for multigrade schools from current PST faculty for training in multigrade classes and transferred them in those schools with special increments.

\section{CONCLUSION}

Primary education in Pakistan suffered a lot due to many challenges. Especially in the primary schools of rural areas, one teacher is posted in a school where he has to teach five to six classes. Research revealed that those teachers face lot of challenges during class management and in other academic process. Mostly they don't complete the courses. Curriculum is prepared for monograde schools and rare alignment is observed in the topics, so the difficulty is felt in making peer groups and collective class teaching. Trainings are conducted for monograde classes only so the teachers lack skills of multigrade pedagogy when they posted in multigrade schools. Participants suggested to increase the incentives of MGT and future appointments may be initiated by creating new posts of multigrade schools as MST-BPS 12 or 15

\section{REFERENCES}

Barbetta, G. P., Sorrenti, G., Turati, G. (2018). Multigrading and child achievement. University of Zurich, Department of Economics, Working Paper, (275).

Dayan, U., Perveen, S., Khan, M. I. (2018). Transition from Pre-Service Training to Classroom: Experiences and Challenges of Novice Teachers in Pakistan. FWU Journal of Social Sciences, 12(2), 48.

Enayati, T.,Zameni, F.,Movahedian, M. (2016). Classroom Management Strategies of Multigrade Schools with Emphasis on the Role of Technology. Interdisciplinary Journal of Virtual Learning in Medical Sciences (IJVLMS), 7(2), 165-179.

Hyry-Beihammer, E. K., Hascher, T. (2015). Multi-grade teaching practices in Austrian and Finnish primary schools. International Journal of Educational Research, 74, 104-113.

Khazaei, Leila, Parvin Ahmadi, Farideh Rahmani, Hamed Bakhshi, Javad Gholipour, and Reza Hosseinpour. "Challenges and disadvantages of multigrade teaching: qualitative research." (2016).

Kucita, P., Maxwell, T. W. (2016). Multi-grade teaching in Bhutan: Congruency amongst policies, teacher education, and practices. EIPEducational Innovation, 1 .

Khan, S., Farooq, R. A., Irshadullah, H. M. (2017). Investigating the Status of Multi-Grade Teaching at Elementary Level in the Province of Khyber Pukhtoonkhwa (Pakistan). Journal of Social Sciences \& Humanities (1994-7046), 25(1).

Kivunja, C., Sims, M. (2015). Perceptions of Multigrade Teaching: A Narrative Inquiry into the Voices of Stakeholders in Multigrade Contexts in Rural Zambia. Higher Education Studies, 5(2), 10-20.

Moeini, S., Moradian, N., Khoroshi, P. (2016). Developing Multi-grade Classes using SWOT Analysis. Mediterranean Journal of Social Sciences, 7(4 S2), 197.

Mulaudzi, M. S. (2016). Challenges experienced by teachers of multi-grade classes in primary schools at Nzhelele East Circuit (Doctoral dissertation).

Muthambi, S. K. (2016). Implications of peer tutoring as multi-grade teaching and learning strategy for learner performance in selected multi-grade schools (Doctoral dissertation).

Pettersson, G., Ström, K., Johansen, J. B. (2016). Teachers' Views on Support in Small Rural Schools for Students with Special Educational Needs. Nordic Studies in Education, 36(01), 20-37.

Qureshi, A. J., Bhutto, A., Mahar, P. R. (2019). Implementation of Free Early Childhood Education and Economic Development: A Case Study of Government Schools In Pakistan. Journal of Business Strategies, 13(1), 125.

Ramrathan, L., Mzimela, J. (2016). Teaching reading in a multi-grade class: Teachers' adaptive skills and teacher agency in teaching across grade $\mathrm{R}$ and grade 1. South African Journal of Childhood Education, 6(2), 1-8.

Shah, R., Das, A., Desai, I., Tiwari, A. (2016). Teachers' concerns about inclusive education in A Ahmadabad, India. Journal of Research in Special Educational Needs, 16(1), 34-45.

Smit, R., Hyry-Beihammer, E. K., Raggl, A. (2015). Teaching and learning in small, rural schools in four European countries: Introduction and synthesis of mixed-/multi-age approaches. International Journal of Educational Research, 74, 97-103.

Soofi, Z.,Akhtar, R. N. (2015). Teachers' Perceptions: Multigrade Classrooms in Primary Schools of Pakistan. Kashmir Journal of Language Research, 18(3).

Taole, M. J. (2017). Identifying the professional knowledge base for multi-grade teaching. Gender and Behaviour, 15(4), 10419-10434.

Tiernan, B., Casserly, A. M., Maguire, G. (2018). Towards inclusive education: instructional practices to meet the needs of pupils with special educational needs in multi-grade settings. International Journal of Inclusive Education, 1-21. 